\title{
Portrayal of Women's Images in Television Dramas: A Malaysian Case
}

\author{
Faridah Ibrahim, Phd $^{1, *}$, Norzita Yunus ${ }^{1}$, Dil Froz Jan Sayed Halem Shah ${ }^{1}$, Munirah Ilias ${ }^{1}$ \\ and Amli Hazlin Ahmad Mokhtar ${ }^{1}$ \\ ${ }^{1}$ Faculty of Arts, Communication and Education, Infrastructure University Kuala Lumpur, Malaysia
}

\begin{abstract}
Current situations brought about by globalisation and sophisticated innovations in new technology not only have created a new understanding of the world around us but also conscientiously sensitised society, particularly the women towards a more active role in shaping their world. An important contributory factor that can determine the success of women is their centrality in the media, through media positions held or through media images portrayed. What this paper has endeavoured to show is the portrayal of women in the media particularly, television dramas. In today's scenario, the role of women keeps changing, so does the portrayal of women's images in television dramas. This paper, based on a qualitative content analysis study of five popular Malaysian television dramas, found that the stereotypical generalizations of women's images are still existing but to a lesser degree.
\end{abstract}

\section{Introduction}

In modern society, with the onset of globalization, the mass media are seen as a powerful tool that can shape behavior and capitalize on the potentials of women which can be used to their advantage. While on the other hand, media reinforces existing stereotypes, attitudes, expectations and values which could be a hindrance to women's advancement in organizations and societies [1]. For decades, we have seen that seminars on mass media at local and international levels have issues of gender as one of their focus.

But in spite of the orientations, emphasis and exposures, the women have not been treated fairly by the media. Except for very few selected personalities, on the overall, media treatment of women can best be described as shallow and narrow. It is contended that on films, drama and soap operas, the newspapers and broadcast media, traditional and new media, women's activities and interests typically go no further than the confines of home and family $[2,3,4]$. Women are rarely portrayed as rational, active and decisive merely because of their dependent, romantic, caring and submissive characteristics. Both as characters in fictional media programs, such as TV dramas or as decision makers portrayed on television news bulletins and newspapers coverage, women are under-represented in

\footnotetext{
*Corresponding Author: faridah@iukl.edu.my
} 
terms of quantity. Such absence has marginalized women and reinforced their inferior status in many spheres.

\subsection{Research Context}

Television dramas are always considered to be a female-viewer-attracted industry. With the advantages of visuals, sound and movement, they have the potential to accentuate social values and popular images of personalities and culture [5]. The dialogues in television dramas have the tendencies to create the images of gender through the languages used and these would leave long lasting impressions in the minds of the audience. Where gender relationship is concerned, the content of the media via media languages and broadcast dialogues have the latent power to emphasize the prominence and dominance of masculinity and femininity. Language is indeed the most sophisticated symbol that mankind has to deal with. Language forms opinion and this becomes patterns and models of the way people perceive things [6]. Furthermore, the images portrayed in television dramas has a definite impact on the thought patterns of society [7]. Hence, positive words would foster good and healthy images for the women and likewise, negative words would conjure negativities. This would be downright harmful for the women and somehow weakens continuous effort to empower them. The paper aims to look at current trends in media portrayals of women via television dramas; what are the dominant images and what are the positive and negative orientations of women's images portrayed in five selected TV dramas in Malaysia.

\subsection{Research Objectives}

This research focuses on the portrayal of women's images in five selected Malaysian television dramas. This research aims to answer the following objectives:

- To identify the dominant themes in the portrayal of women's images

- To identify the positive and negative images of women through selected television dramas.

\section{Literature Review}

Although the situation is not as extreme as in the earlier years, the portrayal of women in television dramas remains divided, showing the dominant social value of masculinity versus femininity. Women are always associated with negativities either through words/dialogues or through actions such as submissive, sensitive, dependent, emotional, bossy, indecisive or fickle-minded. However, the men are usually pictured positively as very rational, independent, assertive and competitive. Two scholars from India [8] found in their study of Indian television serials that women are projected according to the stereotypical image existing in the society leading to reinforcement of stereotypical role. Sex stereotyping is also evident in television portrayal of men and women in their televised roles. Women in the world of television are presented in the role of domestic help, a wife, a mother and being portrayed as submissive and engrossed in common family affection and duties. Men are depicted as employed, spirited and combative.

In Malaysia, the question of female sexuality has proven to still be a critical issue today and was particularly so in post-war Malaya. Most of the studies that looked into the portrayal of women were based on Malaysian films. Several studies found that the image of women was seen from the two-value orientation for instance the dichotomous Virtuous 
versus Fallen/Passionate woman [9]. Other local studies [10, 11, 12] also demonstrate that media imagery of women are profound in Malay movies. Over the past decades, a great deal of movie messages via Hollywood, Bollywood and even 'Mollywood' (the label for Malaysian movie industry) has perpetuated the notion of women as property or commodities "available" for sexual and other use. These messages are played over and over again in movies which show images of women as the gentler sex, having common traits like passivity, weak, needing protection, subservient, scatter-brain, dependent, comforting, nurturing, caring as well as beautiful (so convenient as sex object). The men on the other hand, are pictured with positive traits such as forceful, strong, capable, aggressive, demanding, independent, successful, tycoon, a hero with the stoic macho-man and leadership qualities.

Basically, decisions by media practitioners or program producers regarding portrayal of gender are based on assumptions about the current state of social and cultural values. In most societies, such values incorporate certain definitions of 'masculinity' and 'femininity' which are replayed and reinforced by the media. A study on contemporary Malay movies by [13] found that the male dominance versus female submissiveness dichotomy is dominant. If the movies of the fifties portrayed women as objects of domesticity, contemporary movies portrayed them as objects of sexuality. These modern movies portrayed women in the public sphere as working professionals but once out of their homes, they are seen as objects to be admired, teased, used, desired and played upon by the opposite sex. Such a portrayal about women is not healthy and culturally detrimental.

An earlier study by [14] looked at the detrimental words used by the media, especially the global media, to picture women's images. When the media chose to allocate space on women issues during the 1995 Fourth World Conference on Women in Beijing, they used devilish terms such as 'hardcore feminists', 'burning bras', 'nude women running around the streets of Huairou' and other generalisations and stereotypes which generally eclipsed many positive accomplishments at the Conference.

A comparative study on women's images in Polish and Malaysia's print media $[15,16]$ found that although the study of gender images and representations are undertaken from different cultures, there are some universal similarities. Male dominance is still prevalent and the female gender is still involved in the long continuous struggle to make their presence felt. But on a positive note, the print media in both countries, both magazines and newspapers showed evidences that highlighted the continuous struggle and determination by women in both countries to empower themselves. These evidences were traced from several headlines in the Polish magazines that spell out these words 'A women does not have to..', 'a woman can..', 'a woman is able,' 'a woman conquers the world'. The Malaysian magazines are carrying healthy headlines regarding women such as 'The next generation entrepreneurs..' ' A woman of success...', 'The noble cause and the golden voices..' These evidences showed that more and more women who, inspired by the medial image of a free, liberated, self-determined woman, are trying to change their fate.

\section{Methodology}

This study utilizes the qualitative content analysis approach to collect data pertaining to the themes and dialogues that show reflections of women's images in the selected television dramas. This study is part of a bigger study on women and children's representation in television dramas [17]. For this paper, only a total of five popular Malaysian television dramas were selected for this study namely Sehangat Asmara on Astro, Ariana Rose on TV3, Salju Sakinah on TV Al-Hijrah, Ummi on TV3 and Keluarga Iskandar on Astro. All these TV drama serials were aired on several different television stations in the year 2013 and 2014 and several titles were adaptations from best seller 
novels in Malaysia such as Ariana Rose and Sehangat Asmara. The data were analysed using qualitative content analysis based on recurring themes [18].

\section{Analysis and Discussion}

Three types of genre were observed from the five television dramas that were selected for the study. Ummi and Salju Sakinah come under the drama genre, whilst Sehangat Asmara and Ariana Rose are categorized under the love and romance genre, and Keluarga Iskandar comes under the family genre. In all the drama serials, there are strong women representation in the leading roles as well as strong women characters in the supporting roles. Based on the qualitative content analysis, it is observed that the recurring themes of the dramas is about portraying women as a strong character, and women with great determination. Only one out of 5 dramas understudy showed the main character as a housewife in Keluarga Iskandar who is associated to domestic problems related to families, in-laws and children. There are dialogues in this drama that place the main woman character in a stereotypical generalizations. In Keluarga Iskandar, Kay who is the leading woman character thought that she is pregnant because she has wrongly read the pregnancy gauge. Hence, she goes around telling her in-laws that she is pregnant. Basically, it is supposed to be comical and hilarious but such ignorance is not good for an educated woman like Kay. Some of the dialogues which she uttered do not put her in a positive light. These are the words that have been used: "Urrgh..Acu, tolong kak Ngah ambil air please. Sejak mengandung ni, tulang belakang Kak Ngah rasa macam nak patah." [Acu, please get me some water. Ever since I am pregnant, I feel that my back is so painful]; "Acu, tolong ambil majalah..yang ada exercise sikit tu"[Acu, please get me the magazine, the one with that little exercise]; "Excuse me! Excuse me! Tolong jangan kecoh boleh tak? Saya tengah sakit ni. Sejak mengandung baby ni, macam sakit-sakit sangat badan saya." [Excuse me! Excuse me! Please don't make so much havoc. I am in pain. Ever since I conceive this baby, my body is aching all over"]

Nevertheless, on a positive note, the other four dramas do project a healthy image of the leading women characters. Positive images portrayed by these characters are loving and caring, confidence, patience, intelligent, active, well-mannered, strength, honest, full of spirit, skillful, possess leadership qualities and independent. The study showed high and dominant recurring themes emphasizing active, strength and independent in the leading women characters. This has shifted them from the usual stereotypical generalizations of women who are so dependent on their male partners or counterparts.

Ariana in Ariana Rose is portrayed as a beautiful and highly educated lady who had been raped but had managed to rise in her career as a corporate lady amidst her traumatic experience. She is also noted for her kindness with the orphans and is always thinking of her creator. Her daily prayers had strengthen her faith, "Ampunlah aku Ya Allah. Aku tidak kuat menghadapi ujian mu Yang Allah" [Oh Allah Almighty. Please forgive me. I am not strong to face your test]. Umi in Ummi is a strong-willed lady who is suffering from cancer but is so resilient and spirited to raise her three adopted children. She earn her leaving as a hospital cleaner and selling recycle items.

Kay in Sehangat Asmara who is pregnant and left by her husband is able to stand up and finish her university education to become a successful lawyer. The same goes to Sumayyah in Salju Sakinnah who has to brave herself through hardship in a foreign land. These are good images constructed by the content or program producers. These are positive images that would empower the audience, especially the women.

However, the portrayal of women's images in Malay dramas are seen to be packaged 
with dual image orientations. On one hand, the audience are being fed with positive and good images of women, and on the other, it will be thwarted with some portrayal of bad and negative images of women. These characters also have dominant roles in the dramas but they will usually end up in disaster, mishap and death. They are also pictured as beautiful and successful but unlike the leading characters, they are evil. Mimi, who is Kay's best friend in Sehangat Asmara, died in a car accident after several attempts to destroy Kay's marriage. Puan Sri Syarifah Zaharah, Kay's mother, is not a representation of a good mother. She has schemed with Mimi to destroy her own daughter's marriage. Her evil heart is evidenced in these words: "Nak kahwin, kahwin tapi jangan harap dapat restu dari mak dan ayah. Bila kahwin jangan berani jejak kaki di rumah mak. Mak tak terima Zainal sampai bila-bila, tahu tak?" [You want to marry, go ahead. But don't expect blessings from me or your Dad. And don't step into my house once you are married. I will never accept Zainal as my son-in-law, do you understand?]

Liyana in Ariana Rose died a tragic death after several attempts of plotting to win back Tengku Adam from Ariana. Her evilness was found in these words: "Kalau aku tak dapat miliki kau Adam, tak de siapa yang dapat miliki kau" [If I don't have you Adam, no one else will.]. Beautiful and sexy Liyana even go to the extent of plotting to kill her own brother so that he does not come in between her and Adam.

This study found that although women's representations in the dramas transcend through time, the portrayal of images still remains the same which is dichotomous in nature that defines the images of women as either perfectly good or absolutely bad or evil. Towards a certain extent, these selected television dramas had some empowerment elements which are reflected through the dominant images of women that showed strongwilled women fighting to stand by their own beliefs and values. This study also found that the women's social class, job status, level of education and character traits are being positively depicted more than before. Nevertheless, the images of women holding supporting roles in dramas need not always be stereotypically represented.

\section{Conclusion}

Media content, especially television dramas that portray women and women issues need a reorientation. Present day coverage and programs on women tend to emphasize the $5 \mathrm{~F}$ 's namely Fashion, Food, Family, Furnishing and Fun that spell out to be Femininity. Programs should devote more on people, lifestyles, cultures, attitudes and values and downplay trivialities about women. Television dramas should be more future oriented, rational, highly informative, educational and inspiring that could empower women.

There should be a serious re-look at the media content, both entertainment and news. The media is a powerful tool for education and social change. It has capacity to preserve, record and define human culture and history. Nevertheless, due to insensitivities on the part of content producers, it tend to project stereotypical generalizations of women's images. Although the images of most leading women roles are showing some positive orientations, the supporting women roles in TV dramas are always having negative orientations. Such insinuations are not improving the overall women's images. This calls for a gendersensitized content producers. If the media can shape and structure people's perception of discriminating roles and values, the same institution can be tailored to give a more dynamic and real images of women as human beings in their own rights. Perhaps, it is appropriate to end this paper with a quote from a profound and truly a legendary figure of our time: "Kind words can be short and easy to speak, but their echoes are truly endless" - Mother Teresa 


\section{Acknowledgement}

The findings in this study are extracted from a joint research project funded by IPPTARIUKL 2014-2015.

\section{References}

1. I.Faridah, AMIC Conference (2005)

2. L. Strumska-Cylwik, I. Faridah, IJAS, 7, 5, 647-682 (2014)

3. H.B.K Fuziah, I. Faridah, ICLC Conference. (2002)

4. Faridah, H. Rahmah, JKMJC. 14 (1996)

5. H. Ingham, http://www.aber.ac.uk/mwdia/students/hzi940.html. (2007)

6. L. Strumska-Cylwik, I. Faridah, IJAS, 7, 5, 647-682 (2014)

7. S.Kaul, S. Shahni, Stud Home Comm Sc. 4, 1, 15-20 (2010)

8. S.Kaul, S. Shahni, Stud Home Comm Sc. 4, 1, 15-20 (2010)

9. A.S.H.Kueh, MA thesis. Murdoch University. (1997)

10. H.B.K. Fuziah, I. Faridah, SAMA Conference. (2002)

11. H.B.K. Fuziah, I. Faridah, ICLC Conference. (2002)

12. H.B.K. Fuziah, I. Faridah, ICLC Conference. (2004)

13. H.B.K. Fuziah, I. Faridah, ICLC Conference. (2004)

14. Faridah, H. Rahmah, JKMJC, 14 (1996)

15. L. Strumska-Cylwik, I. Faridah, IJAS, 7, 5, 647-682 (2014)

16. I.Faridah, L. Strumska-Cylwik, IICON-LANCOMME. (2014)

17. I.Faridah (ed), Televisyen: Wanita dan kanak-kanak. Representasi dan pemaparan (IPPTAR-IUKL, Kuala Lumpur, 2015)

18. M.B. Miles, A.M. Huberman. An expanded sourcebook qualitative data analysis, (Sage Publications, London, 1994) 